\title{
Global Geoscience Transects project: Achievements and future goals
}

In portraying the composition and structure of the Earth's crust along long transect lines, the Global Geoscience Transects project of the Inter-Union Commission on the Lithosphere has made great progress over the past 5 years. Regional workshops and business meetings have encouraged local compilers to produce transects that cross national boundaries, and the first seven transects should be published by August 1991. These compilations require research that is both global and interdisciplinary in approach and that depends upon international cooperation.

The project is embarked now upon a new direction in which transect material is being digitized experimentally by using small computers and widely available software. From this work on the Appalachian and Andean transects will come guidelines for digitizing transects, so that in the future, transects should be published both in electronic format and in hard copy. In this process, worldwide, interactive manipulation of geological, geophysical, and geochemical information will become a tool for a new breed-the geoscientist-and will serve to bridge the gaps that exist today among the various geoscientific disciplines. (Ed.)

\section{Introduction}

The Global Geoscience Transects (GGT) project encourages geosci-
entists in all countries of the world to compile cross sections that are
up to a few thousand kilometers in length and are drawn to the base
of the crust and even deeper where data permit. Using all available
geological, geophysical, and geochemical information, geoscientists
draw transects having common scales and formats, so that the Earth's
crust in different parts of the world can be compared directly.
Construction of transects is very much in the spirit of the
Inter-Union Commission on the Lithosphere (ICL), which is a child
of the International Union of Geological Sciences (IUGS) and the
International Union of Geodesy and Geophysics (IUGG). The ICL
encourages geoscientists in all disciplines and, in many cases, from
different countries to work together to understand the evolution and
physical behavior of the lithosphere. Ideally, the result is the best
possible portrayal of the composition and structure of the Earth's crust along the transect line. In practice, attempts to construct transects typically identify the need for more data. outline problems. and thus guide future research.

An early overview of the project and its aspirations was published by J.W.H. Monger (Canada) in Episodes in 1986. After 5 years of work by geoscientists in all parts of the world. the time has come to make this brief review of the progress and accomplishments to date, as well as to indicate the future direction of the project.

\section{Organization and history of the project}

GGT was conceived by ICL at the conference of the International Association of Seismology and Physics of the Earth's Interior (IASPEI) in Tokyo, Japan, in August 1985. Monger was appointed project coordinator in January 1986 by ICL's (past) President Karl Fuchs (Germany). Monger's first task was to organize and chair a multidisciplinary, multinational committee with H.J. Götze (Germany) as Vice-Chairman. Its purposes were to coordinate the global project, develop guidelines for transect compilations. and promote and encourage production of transects in all regions of the world. Monger's second task was initially to use ICL mailing lists and latterly the advice and help of committee members in order to request proposals for transects from ICL National Committees, government geoscience agencies, universities, and scientists. This material was compiled in a transect catalog that contains 41 transect proposals from Africa, 30 from South America, 18 from China, 12 each from the USSR, USA, and Europe, 11 from Australia and New Zealand, 3 from India, and 1 from Southeast Asia (fig. 1). Interest was generated in GGT by holding a series of regional workshops, each of which generally was organized by the host country (table 1 ).

The GGT Coordinating Committee first met in August 1987 at the IUGG XIX General Assembly in Vancouver, Canada, where it developed a preliminary set of guidelines for transect displays in conventional (chart) format. These were based in part on guidelines that had been developed for the successful Decade of North American Geology (DNAG) Continent-Ocean Transects project, which was initiated in 1978 by the U.S. Geodynamics Committee. The project was headed by Robert C. Speed (USA), a member of the GGT Coordinating Committee, and its products were published by the Geological Society of America. The U.S. Geodynamics Committee (1989) recently reviewed the results of the program.

The displays of the DNAG Continent-Ocean Transects project contain the following elements: a geological strip map of a corridor $100-\mathrm{km}$ wide, a geological cross section (vertical scale equals horizontal scale), profiles of gravity and magnetic data. and, where available, seismic-reflection-line diagrams, refraction velocity-depth curves, earthquake hypocenters and epicenters, and heat-flow data. A summary diagram depicts the temporal and spatial relationship of rock units and structures in the display. The "bottom line" integrates all the above information into an interpretative crustal cross section that has rock units colored according to the tectonic setting in which they formed. Thus, the section becomes, in effect, a vertical tectonic 


\section{GLOBAL GEOSCIENCE TRANSECTS}

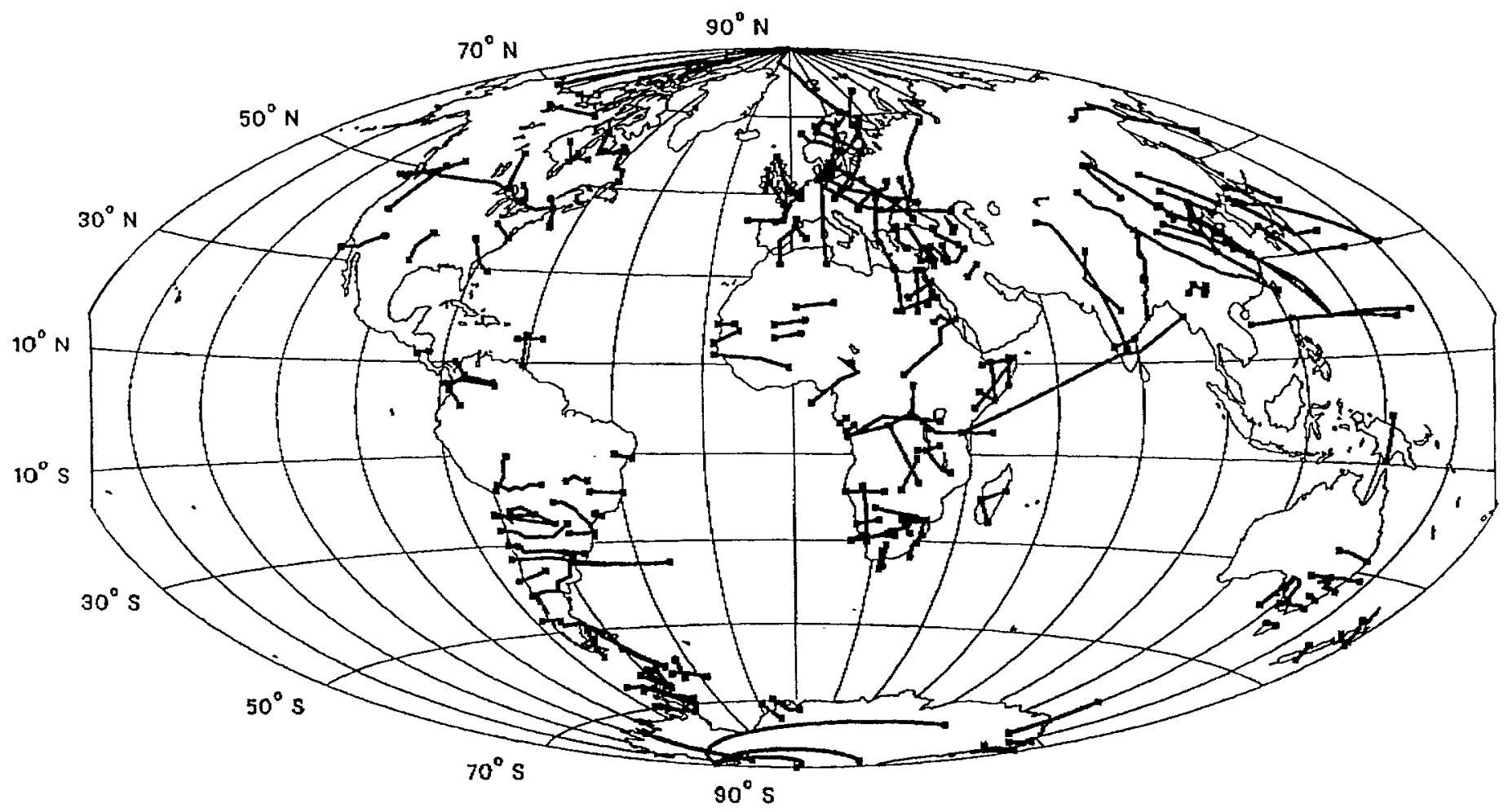

Figure 1. - World map of proposed compilations of Global Geoscience Transects.

map of the Earth"s crust along the transect line, and, ideally, it presents a statement of how that crust was formed. In addition, an accompanying pamphlet amplifies the display and contains references. As a surface-bound field geologist, Monger can attest to the intellectual excitement of working with geophysicists in order to consider the nature and evolution of deeper parts of the crust and to attempt to integrate this data with surface features. One strength of GGT lies in encouraging geoscientists in all countries to feel this excitement by attempting to bridge the gap between surface geology and deeper geophysics, and this is why GGT was conceived as a project of ICL.

GGT guidelines were modified from those of the North Ameriwan program. The latter dealt only with the Phanerozoic fold belts surrounding the Precambrian nucleus of North America, whereas GGT involves the entire surface of the Earth. Because of the length of some transects, the scale was changed for GGT from 1:500,000 to $1: 1,000,000$. Colors used for showing the ages of rock units were modified slightly from the colors used by the Commission for the Geological Map of the World (CGMW). Gravity and magnetic strip maps were employed rather than profiles. At subsequent committee meetings during the VII Latin American Geological Congress in Belém, Brazil, in 1988 and the 28th International Geological Conyress (IGC) in Washington, D.C., USA, in 1989, the guidelines underwent slight modifications in response to deficiencies found by transect compilers. For example, the Archean tectonic features that subsequently have been reworked during younger deformations needed to be shown separately.

Some parts of the world have very complete, freely available data bases, and, exceptionally, there exists the luxury of multichan- nel seismic-reflection data collected for scientific purposes. Other places have, at best, only gravity or aeromagnetic maps as the geophysical data base available for constructing crustal cross sections. In some countries, geophysical data may have been collected, but detailed data are not available, and only generalized data can be displayed. GGT guidelines must be flexible enough to accommodate all these variations.

ICL National Committees and committee members organized regional workshops and business meetings (table 1), and they made heroic efforts to encourage local compilers to produce long transects that cross national boundaries. Regional meetings of broad international participation and great significance for the entire program were held in January 1989 in Cairo, Egypt (Barazangi, 1989), in April 1989 in Beijing, China, and in June 1989 at La Plata, Argentina (Cingolani, 1989). European transect workshops, held in Ostersund, Sweden, in 1988 and in Rudolec, Czechoslovakia, in 1989, innovatively and enjoyably combined field trips and discussions. The results of these efforts were seen clearly at the IGC in Washington in July 1989, where nearly 50 transects were displayed as posters from all parts of the world, including 11 from China and 3 from the USSR that were not listed in the IGC program. In addition, 29 transects were discussed in the GGT symposium.

We have found that GGT compilation plays a significant role both in "geoscience" and in the "education of geoscientists." The problems being investigated are global and interdisciplinary in scope, and international cooperation among geologists, geophysicists, geochemists, and geodesists is required to resolve them. Transect compilations cannot be done without such interdisciplinary research. 
Table 1. -GGT activities 1985-1992 showing date, conference name, location, and name of GGT workshop or business meeting

\begin{tabular}{|c|c|c|c|}
\hline \\
\hline $8.1985:$ & IASPEI Meeting & Tokyo & GGT conceived \\
\hline 11.1985: & & & $\begin{array}{l}\text { Barazangi Map, GGT } \\
\text { proposal to ILP } \\
\text { National Committees }\end{array}$ \\
\hline 12.1985: & AGL Necting & San Francisco & Exploratory Meeting \\
\hline 4.1986: & EGT Workshop & Bad Honnef & GGT Discussion \\
\hline 8.1986: & CPEMR Conference & Singapore & $\begin{array}{l}\text { 1st GGT Proposals } \\
\text { of National Committees }\end{array}$ \\
\hline 2.1987: & CGMW Yeeting & Paris & GGT Discussion \\
\hline 5.1987: & GGT Workshops & $\begin{array}{l}\text { Santiago } \\
\text { Bogota } \\
\text { São Paulo }\end{array}$ & GGT Discussion \\
\hline 8.1987: & IUGG Assembly & Vancouver & $\begin{array}{l}\text { 1st CC-7 Meeting } \\
\text { Intern. Workshop }\end{array}$ \\
\hline \multirow[t]{2}{*}{ 9.1987: } & Intern. Symposium & Irkutsk & $\begin{array}{l}\text { GGT Meeting on } \\
\text { Ritssian Transect Prop. }\end{array}$ \\
\hline & $\begin{array}{l}\text { Congreso Nacional } \\
\text { de Geología }\end{array}$ & Tucuman & $\begin{array}{l}\text { GGT Workshop on } \\
\text { Andean Transects }\end{array}$ \\
\hline \multirow[t]{2}{*}{ 10.1987: } & GSA Annual Meeting & Phoenix & $\begin{array}{l}\text { Workshop on North } \\
\text { American Transects }\end{array}$ \\
\hline & AGE Fall Neeting & San Francisco & $\begin{array}{l}\text { Workshop on Xorth } \\
\text { American Transects }\end{array}$ \\
\hline 11.1987: & SEATAR Mecting & Bangkok & $\begin{array}{l}\text { Workshop on East } \\
\text { Asian Transects }\end{array}$ \\
\hline $7.1988:$ & $\begin{array}{l}\text { Seismin Probing of } \\
\text { Continents and their } \\
\text { Mitrgins }\end{array}$ & Casberra & $\begin{array}{l}\text { Intern. Workshop } \\
\text { Symposium }\end{array}$ \\
\hline 8.1988: & Gondwana Meeting & São Paulo & $\begin{array}{l}\text { Intern. Workshop } \\
\text { on Antarctic Transects }\end{array}$ \\
\hline
\end{tabular}

\begin{tabular}{|c|c|c|c|}
\hline 8.1988: & $\begin{array}{l}\text { Super Deep Drilling } \\
\text { and Geophys. Sounding }\end{array}$ & Jaroslawl & $\begin{array}{l}\text { Intern. Seminar } \\
\text { GGT Poster Session } \\
\text { EUROPROBE }\end{array}$ \\
\hline 9.1988: & $\begin{array}{l}\text { European GGT } \\
\text { Workshop }\end{array}$ & Ostersund & $\begin{array}{l}\text { Intern. Workshop } \\
\text { Poster Session } \\
\text { Fieldtrip }\end{array}$ \\
\hline 10.1988: & $\begin{array}{l}\text { 14. Reumión Científica } \\
\text { de Geofísica y Geodésia }\end{array}$ & Catamarca & $\begin{array}{l}\text { Workshop on South } \\
\text { American Transerts } \\
\text { Poster Session }\end{array}$ \\
\hline 1.1989: & $\begin{array}{l}\text { VII. Congreso Latino } \\
\text { Americano }\end{array}$ & Belem & $\begin{array}{l}\text { 2nd CC-7 Meeting } \\
\text { Symposium } \\
\text { Poster Session }\end{array}$ \\
\hline 1.1989: & $\begin{array}{l}\text { National Committee on } \\
\text { Geophysics and Geodesy }\end{array}$ & Cairo & $\begin{array}{l}\text { Workshop on Middle } \\
\text { East Transects }\end{array}$ \\
\hline 4.1989: & $\begin{array}{l}\text { Chinese Academy of } \\
\text { Geol. Sciences }\end{array}$ & Beijing & $\begin{array}{l}\text { Intern. Workshop } \\
\text { Poster Session } \\
\text { Svmposiurn }\end{array}$ \\
\hline 6.1989: & $\begin{array}{l}\text { South American } \\
\text { GGT Workshop }\end{array}$ & La Plata & $\begin{array}{l}\text { Intern. Workshop } \\
\text { Poster Session }\end{array}$ \\
\hline 7.1989: & 28th IGC & Washington & $\begin{array}{l}\text { 3rd CC-7 Meeting } \\
\text { Symposium } \\
\text { Poster Session } \\
\text { Workshop }\end{array}$ \\
\hline $9.1989:$ & $\begin{array}{l}\text { European GGT } \\
\text { Workshop }\end{array}$ & Rudolec & $\begin{array}{l}\text { Intern. Workshop } \\
\text { Poster Session } \\
\text { Ficldtrip }\end{array}$ \\
\hline 11.1989: & AGU Annual Meeting & St.Louis & $\begin{array}{l}\text { Digitization } \\
\text { Meeting }\end{array}$ \\
\hline
\end{tabular}

\begin{tabular}{|c|c|c|c|}
\hline 4.1990: & EGS Annual Meeting & Copenhagen & $\begin{array}{l}\text { 4th CC-7 Meeting } \\
\text { 1st TG III.1 Meeting } \\
\text { Symposium } \\
\text { Poster Session } \\
\text { Workshop }\end{array}$ \\
\hline 8.1990: & $\begin{array}{l}\text { Regional Seismological } \\
\text { Assembly in Africa }\end{array}$ & Nairobi & $\begin{array}{l}\text { Symposium } \\
\text { Workshop } \\
\text { Poster Session }\end{array}$ \\
\hline 6.1990: & AGL Head Quarters & Washington & 1st Scientific Review \\
\hline 11.1990: & EUROPROBE Meeting & Moscow & Symposium \\
\hline 12.1990: & AGU Fall Meeting & San Francisco & Subcommittee Meeting \\
\hline 12.1990: & GS of Canada & Vancouver & 2nd Scientific Review \\
\hline 8.1991: & $\begin{array}{l}\text { IUGG General } \\
\text { Assembly }\end{array}$ & Vienna & $\begin{array}{l}\text { 2nd TG III.1 Meeting } \\
\text { Symposium } \\
\text { Poster Session } \\
\text { Computer Workshop }\end{array}$ \\
\hline 9.1991: & $\begin{array}{l}\text { Intern. Symposium on } \\
\text { Computer Applications }\end{array}$ & Beijing & $\begin{array}{l}\text { Symposiumi } \\
\text { Computer Workshop }\end{array}$ \\
\hline 9.1991: & $\begin{array}{l}\text { 3rd Intern. Mieeting: } \\
\text { Hcat flow and the } \\
\text { Structure of Lithosphere }\end{array}$ & Beckine & Symposium \\
\hline 10.1991: & AWI Conference & Salta & Symposium \\
\hline 12.1991: & AGL Fall Xeeting & San Francisco & $\begin{array}{l}\text { Subcommittee Meeting } \\
\text { Publication of Digitiza- } \\
\text { tion Guidelines }\end{array}$ \\
\hline 8.1992: & 29 th IGC & Kyoto & $\begin{array}{l}\text { 3rd TG III.1 Meeting } \\
\text { Symposium } \\
\text { Poster Session } \\
\text { Computer Workshop }\end{array}$ \\
\hline
\end{tabular}

\section{Financing of GGT}

As much as possible, the travel and time of committee members for GGT activities are funded by the organizations that employ these individuals. A small amount of funding is available from ICL for the travel of the committee members who are from the less developeif countries. The main financial problem is support for the individual scientists participating in the project from the less developed countries. Who pays for their travel, which is needed in regions wher communication is bad, or for their time if they are diverted from more pressing, economically orientated science? The active participation of scientists in these countries is vitally important to thi global project. One strength of GGT is that all countries can become involved in the project, as it does not demand expensive dataaquisition programs. Much of the data already is acquired and merel needs compilation.

\section{Publication of transects}

Following discussions during the IGC, the American Geophysical Union (AGU), which previously had published many of ICL's prod. ucts, agreed to publish the transects in cooperation with ICL. The first transects, which are in chart format and have accompanyin? descriptive pamphlets, include one from Syria, two from China. two from South America, and two from Australia (one of which in published in cooperation with the Australian Bureau of Mineral Resources). These should be available at the XX General Assembly of IUGG in Vienna, Austria, in August 1991. The transect display, are drafted by the compilers, colored by hand, and scanned b; computers for printing. The cost of standard color-separation printing would have been prohibitively high and would have taken too long. 
These products represent a transitional stage in GGT publications. As discussed below, we hope to publish later transects in electronic format (diskette and compact disc-read-only memory (CD-ROM) forms), although hard copy will be available as well. The digitization of the original seven transects will present no major problems.

\section{Future meetings}

It has taken 2 years to traverse the GGT road from the IGC to the second milestone at the $X X$ General Assembly of IUGG, where the first results of the project will be available. At this meeting, GGT compilers from all parts of the globe will participate in a symposium, convened jointly by ICL and IASPEI on "Plate Tectonic Signatures in the Continental Lithosphere," in a poster session, and in a computer workshop. The workshop will demonstrate and discuss the major new thrust of GGT (discussed below), namely the digitization and manipulation of transect data using small, "low-end" computers. In September 1991, the "International Symposium on Computer Applications in Geoscience" will be held in Beijing and will host a GGT workshop on digitization, which will be organized by Professor $\mathrm{Ma}$, Chairman of the Chinese National Committee for ICL, together with the conference's local organizing committee. Last but not least, the organization of GGT activities during the 29th IGC (Kyoto, Japan, in 1992) already is visible. "New Insight into Processes of Building Continents in the Circum-Pacific Region" is the general focus of GGT activities at the Congress. In this, we hope to use transects to constrain realistically the calculations of rates of crustal growth,

\section{New direction of GGT}

During the annual meeting of the European Geophysical Society (Copenhagen, Denmark, in April 1990), a new committee ("Task Group III. 1" in the new ICL organizational scheme) replaced the Coordinating Committee for GGT. Monger retired as Chairman, and Göze took over the chair. A major reason for this change is the new direction being taken by GGT.

A special GGT Digitization Group was established in 1988. Its formation was catalyzed by comments by Mary Lou Zoback (U.S. Geological Survey (USGS)), encouraged by the U.S. Geodynamics Committee, and included GGT Coordinating Committee members John Harbaugh and Randall Van Schmus, (then) Vice-Chairman Götze, and interested scientists from other institutions in the USA. The purpose of this group was to prepare guidelines for digitizing transects by using small computers and widely available software. Two university groups are working on experimental digitization of transect material using low-cost computer hardware. Richard Williams (Tennessee University, USA) is digitizing the central Appalachian transect, and Götze is working on the central Andean transect. The latter transect was compiled first in analog format by an international and interdisciplinary working group that was headed by Ricardo Omarini of the Universidad Nacional de Salta (Argentina) and included scientists from the Universidad del Norte (Antofagasta, Chile) and Free University, Berlin (Germany).

The GGT guidelines on digitization are based on the experience of digitizing the Appalachian and Andean transects, and these guidelines will be tested publicly at GGT's first computer workshop at IUGG in August 1991. AGU will publish the digitization guidelines, as well as the digitized data bases in electronic format for the two transects. Following this. we hope that the next series of transects will be published in electronic format, although hard copy will be available. This endeavor breaks new ground and goes a long way toward a goal of ICL of closely linking geological, geochemical, and geophysical data bases, as well as breaking down current barriers among different earth science disciplines. For example, geologists can attempt manipulations of gravity data in order to test the validity of their structural models. Digitization of geoscientific material not only will ease the task of publishing transects and will encourage the exchange of data bases, but it promises to allow quantitative comparisons of elements of different parts of the Earth's crust. We feel that the use of digitized transect material is the prefect training ground for a new breed - the geoscientist?

We saw a glimpse of the future in 1989 at the IGC in the form of the Quebec-Maine-Gulf of Maine transect. The compilers, led by David Steward (USGS), used advanced computer technology and an extensive data base in order to produce a detailed transect. This transect includes not only maps of correlated geophysical and geological parameters but also the possibility of three-dimensional compilation (Wright and Steward, 1990; Phillips, 1990). However, we must note that USGS computing facilities are extensive and are available in very few other parts of the world.

GGT's task is to encourage worldwide, interactive manipulation of geological and geophysical information in transect compilation. Our experience shows that "small" computers (such as 286/386 personal computers (PCs)) are available in most parts of the world. Open-file software, mainly written for GGT purposes, will be made available for digitization and modeling of transects. The first steps in encouraging worldwide participation in this direction will be made at the GGT workshop at XX IUGG General Assembly in Vienna.

\section{Digitization: Problems and progress}

In order to establish digitized transects on a worldwide basis, we need to address two separate but related problems: first, modeling and analysis of data and second, computer graphics and related standards. Although computing facilities are available in most parts of the world, they vary enormously in hardware capabilities and in the availability and types of software. GGT digitization guidelines must provide practical guidance for compilations everywhere, regardless of the volume and complexity of data sets or computing facilities. Below, we report on GGT's progress in this direction.

\section{Interactive modeling of transect data}

Future compilations of GGT transects will be based on digitized geographical, geophysical, and geological information and will be produced as CD-ROMs or as diskettes. This material will allow the direct comparison of data from all over the world, and in addition, the common GGT data formats will allow the application of various user-written programs (for example, the Fast Fourier Transformation (FFT) of potential field data, two-dimensional modeling of gravity and (or) magnetic data by interactive program tools, statistical correlations, and much more).

As an example of this interactive modeling of transect data, figure 2 demonstrates a combination of features of our geographical data base (Pacific Ocean coastline, principal settlements, and national borders, for example) and the residual gravity field for the South American central Andes transect. An FFT procedure and a cutoff wavelength of $300 \mathrm{~km}$ were used to separate the gravity field in the area of the transect. Figure 3 shows the corresponding regional gravity field, which is caused mainly by the enormous crustal thickening of Andean crust at the South American western continental margin. Both fields were calculated by Interp, a FORTRAN 77 program (Lahmeyer, 1989) that provides a large number of interpolation and other processing procedures. The plots themselves were created by ISOGKS, an interactive plot program that provides black and white plot facilities, as well as color plots (Schmidt, 1991). The 


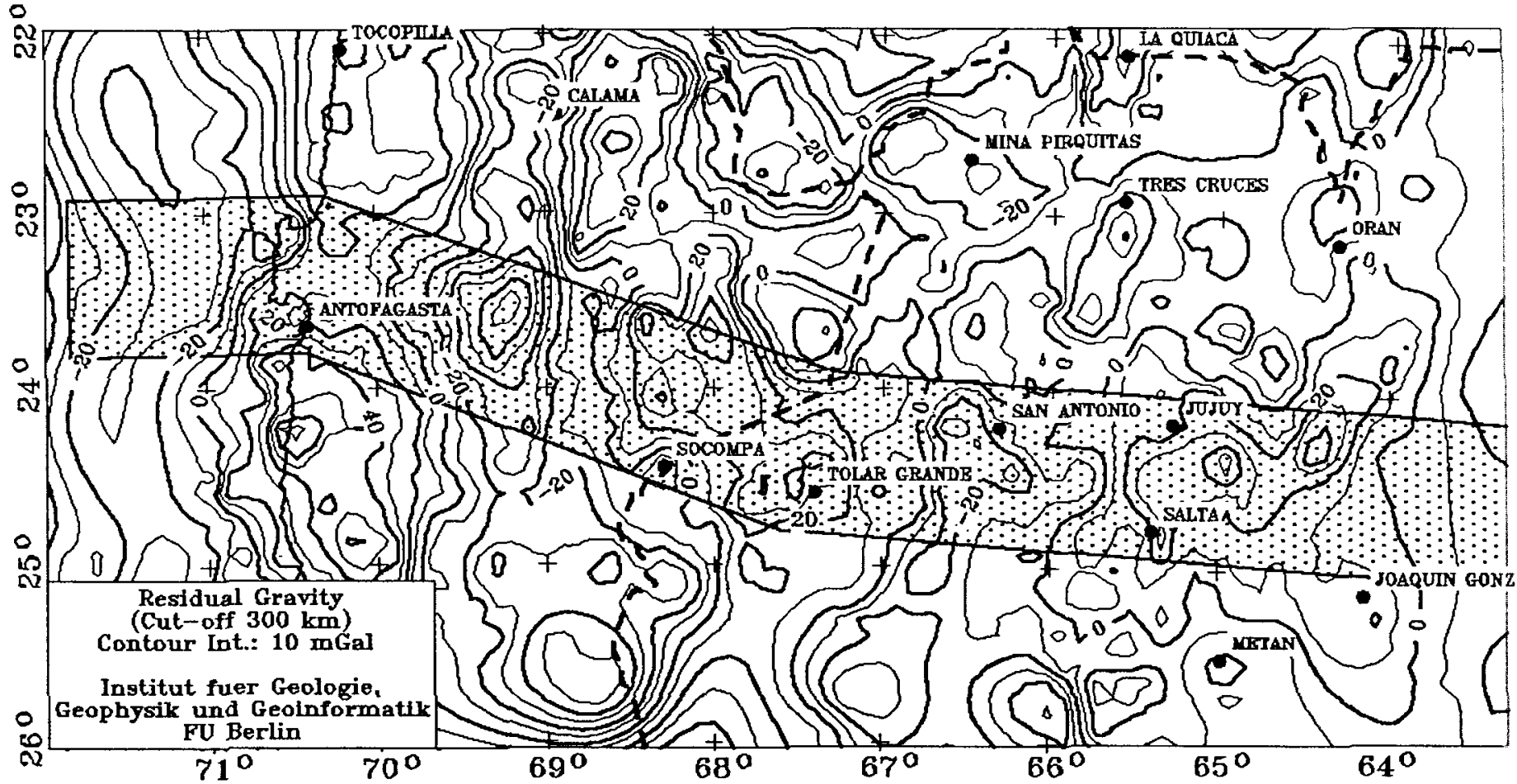

Figure 2.-Residual gravity field of the central Andean transect. The field contains only short wavelengths that are caused by upper and middle crustal structures. Abbreviations: Int., interval; Fu, Freie Universität.

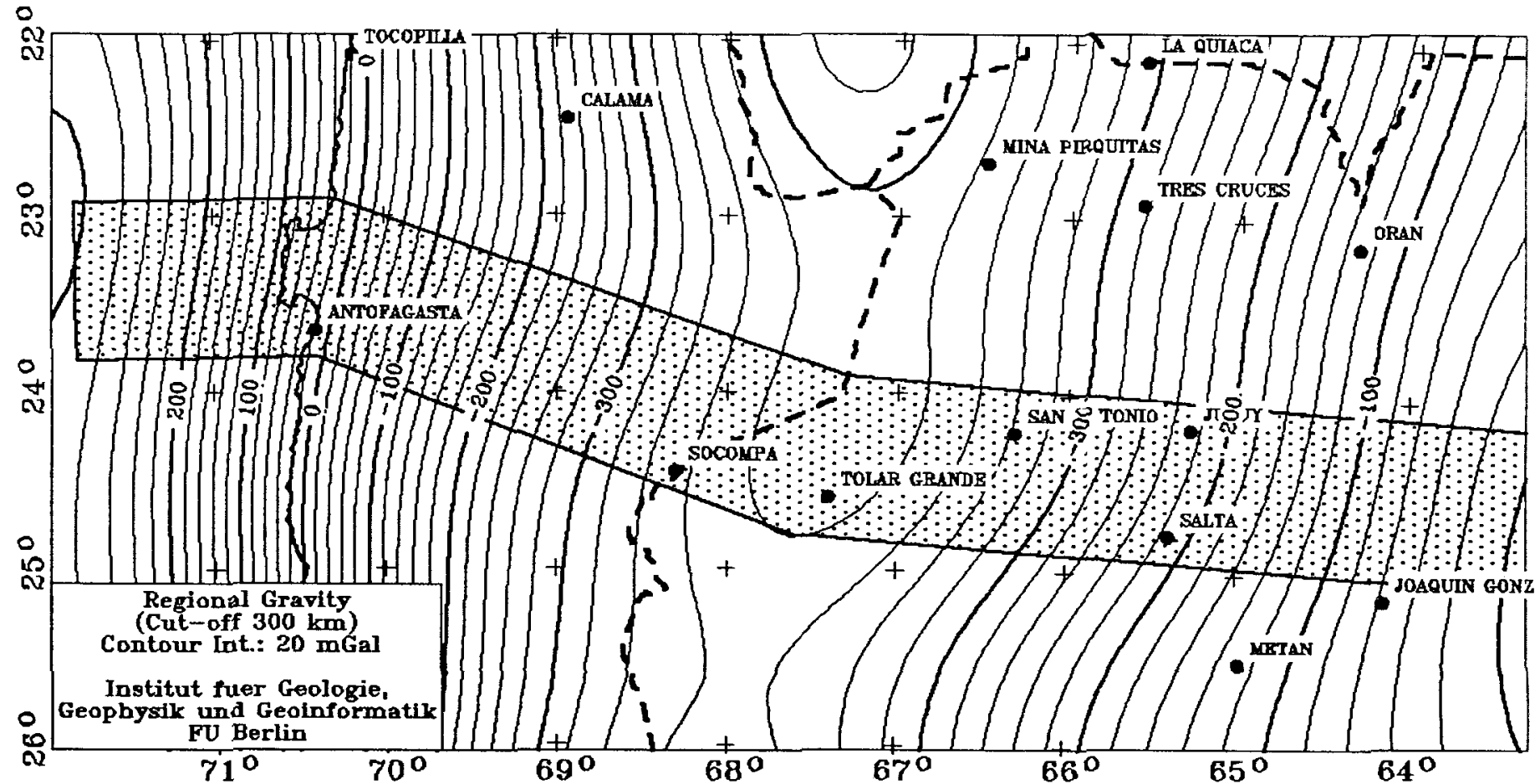

Figure 3.-Regional gravity field caused by the immense thickening of Andean crust at the western continental margin. In the central part of the transect, the crustal thickness is $65-70 \mathrm{~km}$. See figure 2 for abbreviations. 


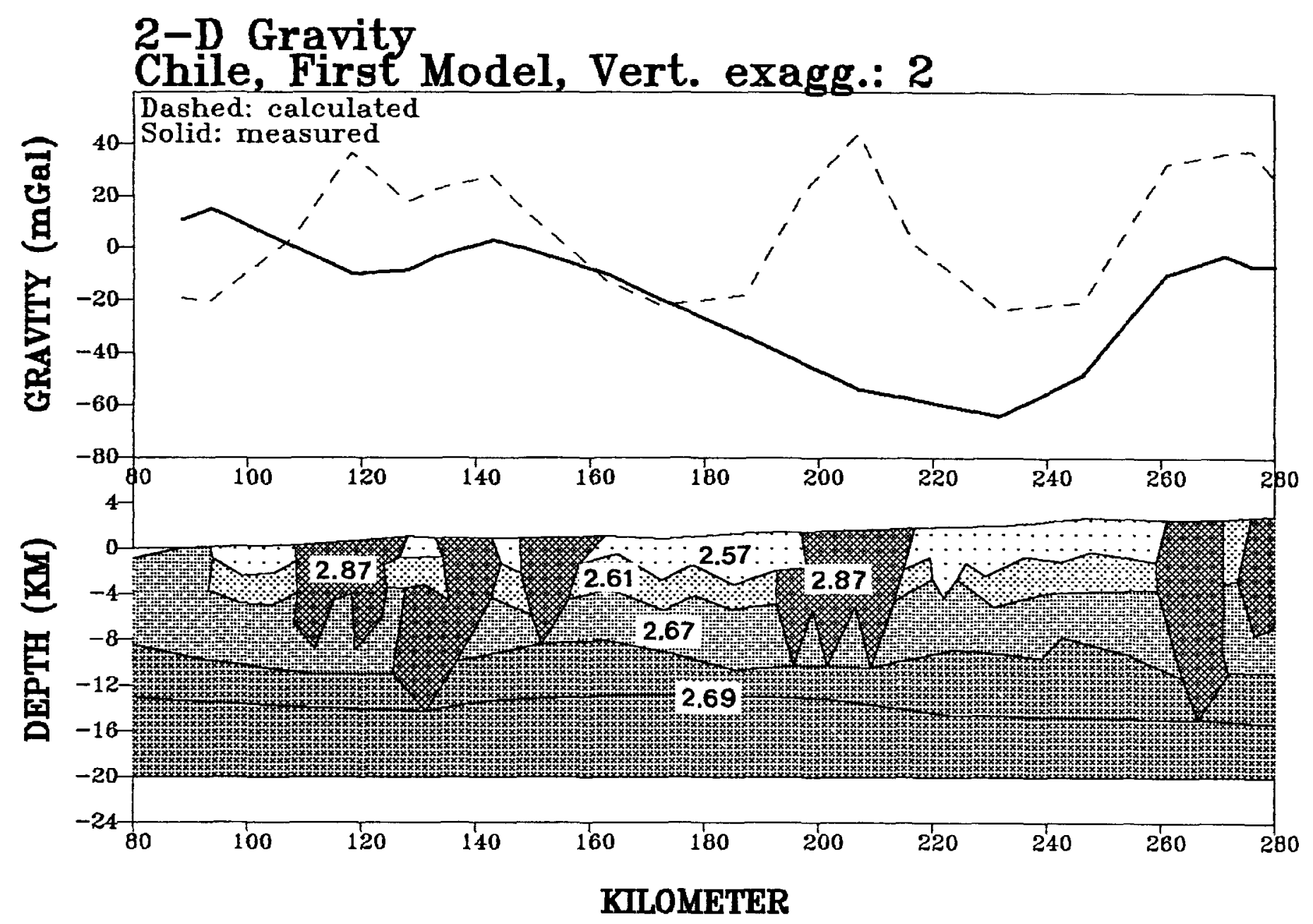

Figure 4.-Testing upper crustal structures by two-dimensional (2-D) gravity modeling of the South American western continental margin. Misfit of theoretical calculated data and measured gravity is obvious and depends on erroneous densities and geometry. Densities are given in $\mathrm{g} / \mathrm{cm}^{3}$. Abbreviation: Vert. exagg., vertical exaggeration.

FORTRAN 77 program includes graphical kernel system subroutines (see the next section) and operates on a 286/386 PC that has an EGA/VGA color screen.

In order to test and verify the uppermost crustal structures of the South American western continental margin, we applied twodimensional gravity modeling. The interactive computer program used here is based on the well-known algorithm developed by Talwani and others (1959). The open-file program called Talwani (authors: Goltz and Schmidt, 1990) provides interactive functions that modify geometry and density, lay out the model on the graphical screen, and plot the modeled results by either plotter or printer. Figures 4 and 5 show a typical Talwani layout. In the upper boxes, the calculated and measured gravity profiles are screened, and in the lower boxes, the crustal cross sections and related densities are given in $\mathrm{g} / \mathrm{cm}^{3}$. In figure 4 , the gravity curves obviously do not fit each other. This results mainly from erroneous densities selected for $\mathbf{J} \mathbf{u}$ rassic and Cretaceous intrusions at profile distances of, respectively, $120-160 \mathrm{~km}$ and $200-220 \mathrm{~km}$. In addition, another, more regional, discrepancy can be eliminated by increasing the thickness of the upper crustal layers from approximately $4 \mathrm{~km}$ to $12 \mathrm{~km}$ on the profile between 200 and $260 \mathrm{~km}$. These modifications (shown in fig. 5) resulted from about 10 interactive sessions at the computer terminal, when Professor Omarini provided geological advice. This example shows the important role of modeling in future transect compilations, and this is a major reason why so much effort has gone into the methods for digitizing compilations.

\section{Computer graphics}

For the purpose of overcoming problems that concern the wide variability of computer graphics (CG), special $\mathrm{CG}$ interfaces for standardization are proposed by both the International Standards Organization (ISO) and (or) the American National Standardization Institute (ANSI) (see Arnold and Bono, 1988). These standards codify the information across an interface between two functional units and specify what is to be changed but not how the units carry out their operations.

For GGT graphics, the guidelines propose two standards that already have been subjected to ISO and ANSI standardization procedures. These are the graphical kernel system (GKS) and the computer graphic metafile (CGM). GKS is a graphics standard that provides the facility to create, from a wide variety of devices, graphical output (on black and white and color displays, printers, and plotters of varying resolutions) and to accept graphical input (from mice, data 


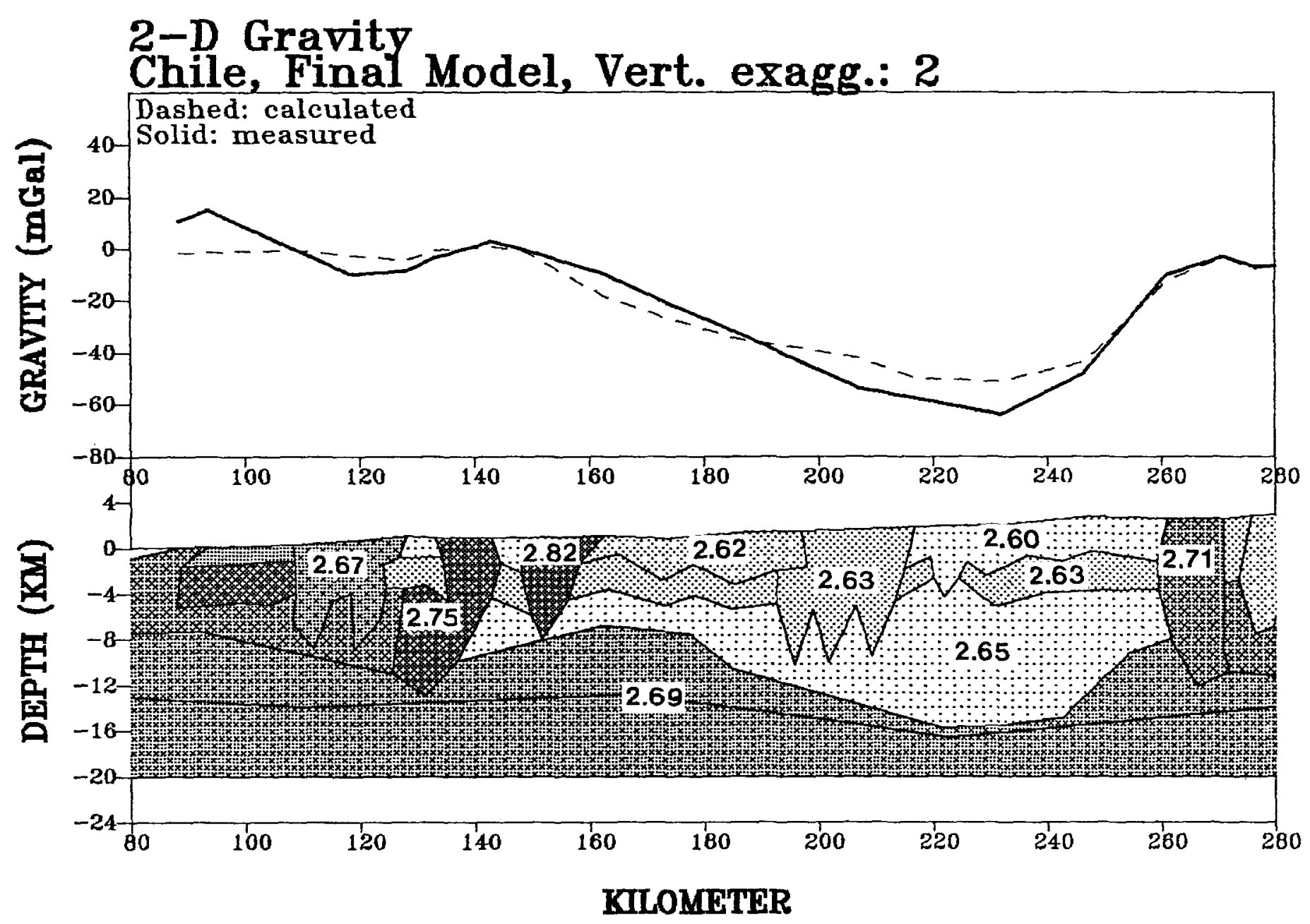

Figure 5. - The final model of the Andean crust at the western continental margin, as it results from interactive terminal sessions. Densities in $\mathrm{g} / \mathrm{cm}^{3}$. Abbreviation: Vert. exagg., vertical exaggeration.

tablets, keyboards, joysticks, and digitizers). GKS's purpose is to allow the creation of views of an object (for example, maps and cross sections), but it is not a system that can support digitization.

GKS implementations are possible within a wide range of hardware, including PC-level and host computers. These implementations provide programming access to GKS from such high-level programming languages as FORTRAN, Pascal, ADA, and C. GKS standards define an exact syntax of GKS functions and data types in each of these programming languages.

In order to exchange pictures (such as maps or cross sections within GGT compilations) among diverse applications and across separate programs, graphical information is used in the CGM. These files can be stored and (or) preprocessed at remote sites as a library of prespecified pictures.

Two principal kinds of graphical metafiles are being standardized. GKS metafiles (GKSM) are not very compact, and if the picture stored in the metafile was created in an interactive manner, the GKSM may contain a large quantity of superfluous information. On the other hand, the CGM represents a "snapshot" of the final image that a program has created. The definitions are compressed by storing only the elements that make up the final picture.

The original GGT guidelines specify the numbers of the individual colored pencils to be used in coloring the author-prepared transect display. Recently we transferred by visual comparison the hues of colored pencils to computer-generated colors. Color codes for potential field maps, geological maps, and cross sections, as well as for the tectonic settings in the interpretative cross sections, were used in an "open-file" application program that contains subroutines of the GKS package. These color codes ensure uniform presentation of colors to be used in all GGT graphical applications around the world.

\section{Conclusion}

The first 5 years of the Global Geoscience Transects project were devoted to establishing guidelines for the project, advertising it, and ensuring that geoscientists were working on the transects. The initial products of this first phase will be available at the $\mathrm{XX}$ General Assembly of IUGG in Vienna in August 1991. The next phase of the project involves digitizing transect data in globally compatible formats that can be handled by small computers and widely available hardware so that scientists in all countries can participate. These formats promise to allow direct, quantitative comparisons between different kinds of data from all regions of the Earth and, by allowing 
interactive manipulation of all kinds of geoscientific data, to bridge the gaps between the various geoscientific disciplines.

\section{Acknowledgments}

The authors thank their colleagues who have served at various times on the GGT Coordinating Committee for their efforts over the last 5 years. These colleagues are M. Barazangi, USA; C. Cingolani, Argentina; U. Cordani, Brazil; I.W.D. Dalziel, USA; D. Gee, Sweden; Harsh Gupta, India; J. Hasrbaugh, USA; E.W. Kharus, USSR; M. Kono, Japan; M. Kulvanich, Thailand; Ma Xingyuan, China; M.J. Rickard, Australia; B.T. Rumvegeri, Zaire; R.C. Speed, USA; J. Sougy, France; J. Sweeney, Canada; and W.R. Van Schmus, USA. In addition, acknowledgment also should be made here of the whole-hearted support of GGT by the U.S Geodynamics Committee and especially by its secretary, Dr. Pembroke Hart. This support was manifested not only by advice but also by freely distributing products of the North American program to interested GGT participants. Last, but not least, we wish to thank our generous hosts in many countries of the world, who, in addition to their scientific contributions, made our visits to their countries pleasurable.

\section{References}

Amold, D.B., and Bono, P.R., 1988, CGM and CGI: Metafile and interface standards for computer graphics: Berlin, Springer-Verlag, $279 \mathrm{p}$.

Barazangi, M., 1989, Transect workshop held in Egypt: EOS (American Geophysical Union Transactions), v. 70, p. 581 .

Cingolani, C.A., 1989, Actas Reunión sobre Geotransectas de America del Sur: Montevideo, Uruguay, Departamento Apoyo Pedagógico, Facultad de Agronomía.

Goltz, G., and Schmidt, S., 1990. Talwani, an interactive 2D programming tool for gravity modeling: Berlin, Freie Universität, Institut für Geologie, Geophysik und Geoinformatik.

Lahmeyer, B., 1989, Anwendungen der schnellen Fouriertransformation und der Quadratischen Programmierung bei der Interpretation von Schwerefeldern: Berlin, Freie Universität, Institut für Geophysikalische Wissenschaften, Ph.D. thesis.

Monger, J.W.H., 1986, The Global Geoscience Transects project: Episodes, v. 9, p. 217-222.

Phillips, J.D., 1990, Integration of potential field and digital geologic data for two North American geoscience transects: Journal of Geological Education, v. 38 , p. $330-338$.

Schmidt, S., 1991, ISOGKS, a short description: Berlin, Freie Universität, Institut fur Geologie, Geophysik und Geoinformatik.

Talwani, M., Worzel, J.L., and Landisman, M.G., 1959, Rapid gravity computations for two-dimensional bodies with application to the Mendocino submarine fracture zone [Pacific Ocean]: Journal of Geophysical Research, v. 64, p. 49-59.

U.S. Geodynamics Committee, 1989, North American Continent-Ocean Transects Program: Washington, D.C., National Academy Press, 87 p.

Wright, B.E., and Stewart, D.B., 1990. Digitization of a geologic map for the Quebec-Maine-Gulf of Maine global geoscience transect: U.S. Geological Survey Circular 1041, 16 p.

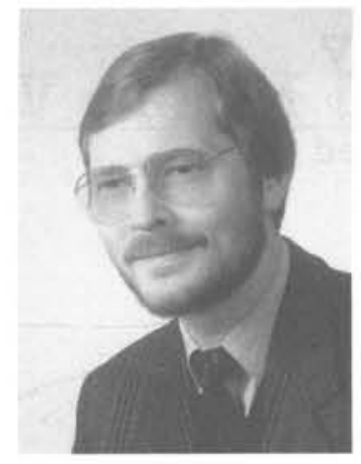

Dr. Hans-Jürgen Götze is a Professor at the Institut für Geology, Geophysik und Geoinformatik of Freie Universität Berlin (Germany), where he teaches both applied geophysics and theory. He has been Chairman of ICL's Task Group III.I (Global Geoscience Transect Program) since 1990 and is a member of the Society of Exploration Geophysicists, American Geophysical Union, European Association of Exploration Geophysicists, and the German Geophysical Society.

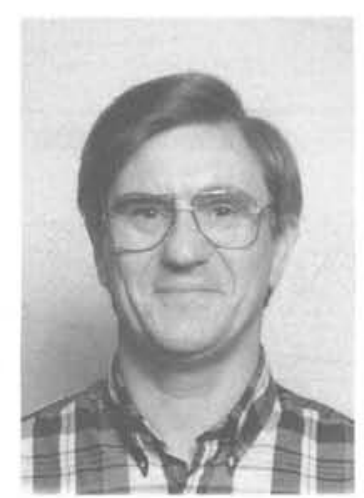

Dr. James W.H. Monger, past Chairman of the Coordinating Committee for GGT, is a geologist with the Geological Survey of Canada. Based in Vancouver (Canada), he is engaged in regional mapping and tectonic syntheses of the Canadian Cordillera. 